\title{
Comparative Study of High Quality Genomic DNA Extraction Protocols in Rice and Tomato Crops
}

\author{
Shiv Mani Dubey, Sujeet Kumar*, S.H. Antre and P.H. Ramanjini Gowda
}

Department of Plant Biotechnology, University of Agricultural Sciences,

GKVK, Bengaluru-560065, Karnataka, India

*Corresponding author

\section{A B S T R A C T}

\begin{tabular}{|l|}
\hline K e y w o r d s \\
$\begin{array}{l}\text { Oryza sativa, Solanum } \\
\text { lycopersicum, DNA } \\
\text { extraction, Genomic } \\
\text { DNA, DNA purity. }\end{array}$ \\
\hline Article Info \\
\hline $\begin{array}{l}\text { Accepted: } \\
\text { 20 September } 2017 \\
\text { Available Online: } \\
\text { 10 November } 2017\end{array}$ \\
\hline
\end{tabular}

This study presents a rapid efficient DNA extraction protocol for rice and tomato crops. Five published protocols (Doyle \& Doyle CTAB Procedure, Urea Method, Salt extraction method, IRRI Method, Dellaporta DNA Extraction method) were comparatively evaluated in rice and tomato crops for DNA purity and yield. The analysis of variance revealed that the yield was significantly different $(\mathrm{P}<0.01)$ for all protocols in both crops, whereas there was no significant observation was observed for purity. The multiple Duncan test revealed that, Doyle \& Doyle CTAB Procedure was best for rice crop $(2481 \mathrm{ng} / \mu \mathrm{l})$, whereas urea method was best for tomato crop $(2685 \mathrm{ng} / \mu \mathrm{l})$. Here Proposed that urea method, Doyle \& Doyle CTAB Procedure is best method for good quality DNA and higher yield in tomato and rice crop respectively. Hence this method of extraction would be ideal for genotyping of large populations of rice and tomato genotypes.

\section{Introduction}

Biotechnology has emerged the most important new resource for achieving the global food production through release of new variety early. The emergence of plant transformation and molecular marker analyses in genome studies has greatly enhanced the speed and efficacy of crop improvement and breeding programmes. A prerequisite for taking advantage of these methods is the ability to isolate genomic DNA of superior quality and quantity for analyzing through Polymerase Chain Reaction (PCR), restriction enzyme digestion and subsequent Southern blot hybridization. The quality and quantity of DNA required depend upon the objective.
For marker assisted selection the amount of DNA needed is small and need not be stored for a long duration where as in QTL mapping or population studies of RILS, $\mathrm{F}_{2}$ population required large amount of DNA (McCarthy et al., 2002; Guo-Liang et al., 1993) and also stored for long duration. However, to obtain accurate result, it is necessary to isolate good quality DNA that is relatively free from the many contaminants found in plant cells (Jobes et al., 1995).

DNA extraction is used in the genetic modification of plants. Many agricultural companies use genetic extraction to create 
DNA that they then modify to make a particular genetic strain of a crop that is resistant to various chemicals or pests. The DNA sequencing reliability entirely depends upon on purity and yield of DNA. Among the cereals and vegetables rice and tomato are very important crops respectively. Nowadays, crop improvement works are going on these crops such as cold tolerance in tomato and aerobic rice in case of rice. For crop improvement programme, the genomic DNA should be pure and high yield. A vital protocol of genomic DNA isolation helps in molecular characterization in these crops. Although Several protocols are available for genomic DNA isolation such as Dellaporta et al., 1983; Chang et al., 1993; Sperisen et al., 2000; Sharma et al., 2003; Kang and Yang, 2004; CTAB method (Doyle and Doyle, 1987) and its modified protocol (Huang et al., 2000; Rogers and Bendich, 1985), procedures etc. But all these protocols don't give promising result in all cases. CTAB methods also have some demerits of obscuring absorbance readings at $260 \mathrm{~nm}$ due to the interference of residual $\mathrm{CTAB}$ in the final DNA solution (Doyle \& Doyle, 1990). Liquid nitrogen and proteinase $\mathrm{k}$ are needed for CTAB protocols that are very expansive.

The choice of a method depends on many factors; the required quantity and molecular weight of the DNA, the purity required for downstream applications, time and expense. Since size, content and organization of genome and contents of metabolites of different plant systems vary from each other to a great extent, a single DNA isolation protocol is not likely to be applicable to all plant systems (Loomis, 1974). In recent decades, a well-known use for genetic extraction is germplasms characterization, genetic diagnostics, characterization of transformants, study of genome organization, phylogenetic analysis, marker-assisted selection, mapping Quantitative Trait Loci
(QTL), DNA sequencing etc. (Gupta et al., 1999). For these works need pure and high yield of DNA in limited resources.

Keeping in view the above point, the present experiment was conducted to identify the best DNA isolation method suited for isolation of reasonably pure DNA in sufficient amount from rice and tomato leaves that can be stored for a longer duration and lasting for several $\mathrm{PCR}$ reactions.

\section{Materials and Methods}

\section{Collection of plant sample}

The plants used for genomic DNA extraction were grown in a greenhouse. The leaf sample was collected from rice variety-IR 64 and tomato variety Arka Alok. Rinsed the leaf sample in running tap water then dried and stored for $24 \mathrm{hrs}$ in a deep freezer a $\left(-20^{\circ} \mathrm{C}\right)$. In all method DNA was extracted without using liquid nitrogen.

\section{DNA extraction}

The DNA was extracted from healthy fresh young leaf tissue of rice and tomato variety with four replications by following five published protocols viz: A. Doyle \& Doyle CTAB Procedure (Doyle \& Doyle, 1987) B. Urea Method (Nalini et al., 2003) C. Salt extraction method (Aljanabiand Martinez, 1997) D. IRRI Method, (Zheng et al., 1995) E. Dellaporta DNA Extraction method, (Dellaporta et al., 1983). The DNA was extracted by all five methods in both crops with four replications.

\section{Doyle \& Doyle CTAB procedure (Doyle \& Doyle, 1987)}

$5.0-7.5 \mathrm{ml}$ of CTAB isolation buffer (2\% cetyltrimethyl ammonium bromide [CTAB], $1.4 \mathrm{M}$ sodium chloride $[\mathrm{NaCl}], 0.2 \% 2-$ 
mercaptoethanol, $20 \mathrm{mM}$ ethylenediamine tetra acetic acid [EDTA], $100 \mathrm{mM}$ Tris- $\mathrm{HCl}$, $\mathrm{pH}$ 8.0) was preheated in a $30 \mathrm{ml}$ glass centrifuge tube to $60{ }^{\circ} \mathrm{C}$ in a water bath. Fresh leaf tissues were collected $0.5 \mathrm{~g}$ and grinded in CTAB isolation buffer in a preheated mortar. Samples were then incubated at $60^{\circ} \mathrm{C}$ for $30 \mathrm{~min}$. with occasional gentle swirling. Then it was extracted with chloroformisoamyl alcohol (24:1), by mixing gently followed by centrifugation at $6,000 \mathrm{x} \mathrm{g}$ for 10 min. at room temperature. Aqueous phase was removed with wide bored pipette and transferred to clean glass centrifuge tube in which $2 / 3$ volumes cold isopropanol was then added to precipitate nucleic acids for an hour. After precipitation of nucleic acid, the supernatant carefully removed and washed with $70 \%$ ethanol gently followed by allow it to air dry briefly at room temperature. Finally nucleic acid pellet was re-suspended in $100 \mu \mathrm{l}$ TE (10 mM Tris-HCl, 1 mM EDTA, pH 7.4).

\section{Urea Method (Nalini, et al., 2003)}

The $0.5 \mathrm{~g}$ of leaf tissue was grinded in mortar after adding $2 \mathrm{ml}$ of extraction buffer. The extraction buffer ( $\mathrm{pH}$ 8.0) contains $100 \mathrm{mM}$ Tris, $20 \mathrm{mM}$ EDTA, $0.5 \mathrm{M} \mathrm{NaCl}, 7 \mathrm{M}$ Urea, $0.1 \% \beta$-mercaptoethanol and $2 \%$ Sodium dodecyl sulfate [SDS]. The homogenates were transferred to a $2 \mathrm{ml}$-microfuge tubes. An equal volume of phenol: chloroform: Isoamlyalcohol (25:24:1) was added to the tubes and mixed well.The tubes were centrifuged at room temperature for $15 \mathrm{~min}$. at $15,000 \mathrm{rpm}$. The upper aqueous phase was collected in a new tube and an equal volume of chloroform: Isoamlyalcohol (24:1) was added and mixed. The upper aqueous phase obtained after centrifuging at room temperature for $10 \mathrm{~min}$. at $15,000 \mathrm{rpm}$ was transferred to a new tube. The DNA was precipitated from the solution by adding 0.1 volume of $3 \mathrm{M}$ Sodium acetate $\mathrm{pH} 7.0$ and 0.7 volume of Isopropanol. After $15 \mathrm{~min}$. of incubation at room temperature the tubes were centrifuged at $4^{\circ} \mathrm{C}$ for $15 \mathrm{~min}$. at 15,000 rpm. The DNA pellet was washed with $70 \%$ ethanol and then very briefly with $100 \%$ ethanol and air dried. The DNA was dissolved in $100 \mu \mathrm{l}$ TE (Tris-Cl $10 \mathrm{mM} \mathrm{pH} \mathrm{8.0,} \mathrm{EDTA}$ $1 \mathrm{mM}$ ).

\section{Salt Extraction Method (Aljanabiand Martinez, 1997)}

The fresh $0.5 \mathrm{~g}$ tissue was homogenized in $400 \mu \mathrm{l}$ of sterile salt homogenizing buffer $(0.4$ $\mathrm{M} \mathrm{NaCl} 10 \mathrm{mM}$ Tris-HCl pH 8.0 and $2 \mathrm{mM}$ EDTA pH 8.0), using a Polytron Tissue Homogenizer, for $10-15 \mathrm{sec}$. Then $40 \mu 1$ of 20 $\%$ SDS ( $2 \%$ final concentration) and $8 \mu 1$ of $20 \mathrm{mg} / \mathrm{ml}$ protenase $\mathrm{K}(400 \mu \mathrm{g} / \mathrm{ml}$ final concentration) were added and mixed well. The samples were incubated at $55-65{ }^{\circ} \mathrm{C}$ for at least $1 \mathrm{hr}$. or overnight, after which $300 \mu \mathrm{l}$ of $6 \mathrm{M} \mathrm{NaCl}\left(\mathrm{NaCl}\right.$ saturated $\left.\mathrm{H}_{2} \mathrm{O}\right)$ was added to each sample. Samples were vortexed for $30 \mathrm{~s}$ at maximum speed, and tubes spun down for $30 \mathrm{~min}$ at $10000 \mathrm{~g}$. The supernatant was taken and transferred to fresh tubes. An equal volume of isopropanol was added to each sample, mixed well, and samples were incubated at $-20{ }^{0} \mathrm{C}$ for $1 \mathrm{hr}$. Samples were then centrifuged for $20 \mathrm{~min}, 4^{\circ} \mathrm{C}$, at $10000 \mathrm{~g}$. The pellet was washed with $70 \%$ ethanol, dried and finally resuspended in $100 \mu \mathrm{TE}$ (Tris-Cl 10 mM pH 8.0, EDTA 1 mM).

\section{IRRI Method (Zheng et al., 1995)}

The $0.5 \mathrm{~g}$ Leaf tissue was grinded in $200 \mu \mathrm{l}$ extraction buffer [Tris-HCl $50 \mathrm{mM}(\mathrm{pH} \mathrm{8})$, EDTA $25 \mathrm{mM}, \mathrm{NaCl} 300 \mathrm{mM}$, SDS 1\%]. After grinding, $300 \mu \mathrm{l}$ of extraction buff er was added and transferred to $1.5 \mathrm{ml}$ tube containing another $500 \mu \mathrm{l}$. In order to remove proteins, $500 \mu \mathrm{l}$ chloroform/isoamylalcohol (24:1) was added to the tube and mixed by inversion. The samples were then centrifuged for $1 \mathrm{~min}$ at $15115 \mathrm{~g}$. Supernatant $(750 \mu \mathrm{l})$ 
was removed and $750 \mu \mathrm{l}$ of $100 \%$ ethanol was added to precipitate the DNA. After mixing by gentle inversion, the samples were centrifuged for $3 \mathrm{~min}$. at $>13000 \mathrm{rpm}$. The supernatant was then discarded and washed with $70 \%$ ethanol. The pellet was then dried by leaving on the on bench at room temperature for at least $20 \mathrm{~min}$ (for the evaporation of residual ethanol). Finally, the DNA was re-suspended in $100 \mu \mathrm{l}$ of TE Buff er $(10 \mathrm{mM}$ TrisHCl, $1 \mathrm{mM}$ EDTA $\mathrm{pH}$ 8.0) and stored at $-20^{\circ} \mathrm{C}$.

\section{Dellaporta DNA extraction method (Dellaporta, et al., 1983)}

Weigh $0.5 \mathrm{~g}$ of tissue, freeze in $-80^{\circ} \mathrm{c}$ and grind to fine powder in a mortar and pestle. Transfer the fine powder into a $30 \mathrm{ml}$ Oak Ridge Tube and add $15 \mathrm{ml}$ extraction buffer. Add $1 \mathrm{ml}$ of $20 \%$ SDS to each tube. Make sure libs are screwed on tightly.

Mix thoroughly by vigorous shaking, and then incubate tubes in a $65^{\circ} \mathrm{C}$ water bath for 10 min. Add $5 \mathrm{ml}$ of $5 \mathrm{M}$ Potassium acetate [KOAC]. Mix thoroughly by vigorous shaking, then incubate tubes at $0^{\circ} \mathrm{C}$ (on ice) for $20 \mathrm{~min}$. Spin tubes at 13,000 rpm for 20 min. in a Sorval centrifuge with the SA-600 rotor( 25,000 x g) Pour supernatant through Miracloth (cheesecloth) into a $30 \mathrm{ml}$ Oak Ridge Tube containing $10 \mathrm{mM}$ isopropanol invert 20 times to mix well and incubate at $20{ }^{\circ} \mathrm{C}$ for $30 \mathrm{~min}$. Spin tubes at $12,000 \mathrm{rpm}$ for $15 \mathrm{~min}$. in a Sorval centrifuge with the SA-600 rotor( $20,000 \times \mathrm{g})$.

\section{DNA quantification}

The amount of genomic DNA was quantified by ND-1000 spectrophotometer (Nano Drop inc. 2007). The purity of genomic DNA of rice and tomato was measured by obtaining the absorbance ratio A260/280 using the Nanodrop spectrophotometer.

\section{DNA purification}

The genomic DNA was treated with $10 \mu$ of (10 U/ $\mu \mathrm{l}) \mathrm{RNase} \mathrm{A}$. Incubate at $37^{\circ} \mathrm{C}$ for 10 min. after that sample was inactivated by heat treatment at $70^{\circ} \mathrm{C}$ for $15 \mathrm{~min}$. and kept sample on ice to cool. For ethanol precipitation added $1 / 10$ volume of $3 \mathrm{M}$ Sodium Acetate and 2.5 volumes of $100 \%$ ethanol mixed the sample and Placed at $-20^{\circ} \mathrm{C}$ overnight. The sample centrifuged at $4^{0} \mathrm{C}$ for 20 min. washed the pellet with $70 \%$ ethanol (cold). Spin sample at $13,000 \mathrm{rpm}$ at $4^{0} \mathrm{C}$ for 3-5 min. The pellet dried and resuspend with $100 \mathrm{ul}$ of TE buffer.

\section{Agarose gel electrophoresis}

To evaluate the quality and intactness of the extracted DNA, gel electrophoresis was used. The extracted DNA of both crop tomato and rice $500 \mathrm{ng} / \mu \mathrm{l}(5 \mu \mathrm{l})$ was loaded on $0.8 \%$ agarose gel (Genei, Bangalore), which contained ethidium bromide for DNA staining. For image acquisitions, gels were visualized under UV light and documented by using the gel documentation system (Alpha Innotech, Fluor ChemR FC2).

\section{Statistical analysis}

The mean and variance of yield and purity of genomic DNA mentioned above were subjected to statistical analysis by $\mathrm{R}$ software 3.0 (online free version).

\section{Results and Discussion}

The result of analysis of variance revealed that significant differences were observed between the mean DNA yields of rice and tomato using the five methods (Table 1). There was no significant variance observed for DNA purity of both crops using all methods. It is due to the genomic DNA was treated with Rnase A enzyme so RNA 
contamination was eliminated. The result of Duncan's Multiple Range Test state that all five method of the mean yield of DNA were significantly different in both crop rice and tomato (Table 2). In rice, the genomic DNA yield was maximum observed by Doyle \& Doyle CTAB Procedure, (2481 $\mathrm{ng} / \mu \mathrm{l})$ followed by Urea Method (1928 ng/ $\mu \mathrm{l})$, Dellaporta DNA Extraction method (1235 $\mathrm{ng} / \mu \mathrm{l})$ whereas, in tomato, the maximum was observed by Urea Method (2685 ng/ $\mu \mathrm{l})$ followed by Dellaporta DNA Extraction method (1979 ng/ $/ \mathrm{l})$ and Doyle \& Doyle CTAB Procedure (1419 ng/ $\mu$ l) (Table 3).

The amount of DNA was obtained in rice $2481 \mathrm{ng} / \mu \mathrm{l}$ and in tomato $1419 \mathrm{ng} / \mu \mathrm{l}$ by Doyle \& Doyle CTAB Procedure. It indicates that this method is good for high amount of DNA isolation in both crops. CTAB is an ionic detergent, which form an insoluble complex with nucleic acids in a low salt environment. Under these conditions, polysaccharides, phenolic compounds and other contaminants remain in supernatant and can be washed away. The DNA complex is solubilised by raising salt concentration resulting a good yield and purity.

The yield and purity of genomic DNA were compared in both of the crops for all the methods. By Doyle \& Doyle CTAB Procedure, amount of DNA was maximum in rice crop where as in tomato third most. The amount of DNA was low and purity also poorer in both crops rice and tomato crops by IRRI Procedure therefore this method is not suitable for longer storage and genotyping of the crops.

By urea method, the amount of DNA was maximum in tomato sample $(2685 \mathrm{ng} / \mu \mathrm{l})$ and second most in rice sample $(1928 \mathrm{ng} / \mu \mathrm{l})$. This amount of DNA yield was better than recent studies (Laxmi prasanna et al., 2013; Healey et al., 2014; Rawat et al., 2016; Sajib et al.,
2017). Urea is a chaotropic agent, and its role is to remove DNA from the histones and denature other proteins and promote more stability to the system. Sodium dodecyl sulphate (SDS) is a strong anionic detergent that can solubilize the proteins and lipids that form the membranes. This helps to rupture cell membrane and nuclear envelop and expose the chromosomes that contain the DNA. In addition to remove the membrane barriers, SDS helps release the DNA from histones and other DNA binding proteins by denaturing them. Hence in urea method, the urea along with SDS helps to get a higher concentration of DNA. Nalini et al., (2003), DNA was obtained on an average $200 \mu \mathrm{g}$ of from the $0.5 \mathrm{~g}$ of leaf tissue of wheat plants. For PCR reaction $100 \mathrm{ng}$ is required for one reaction so this amount of DNA is sufficient for 2000 reactions. In present study, the amount of DNA was obtained $2685 \mathrm{ng} / \mu \mathrm{l}$ from $0.5 \mathrm{~g}$ of leaf tissue of tomato and total volume maintained at $100 \mu \mathrm{l}$ which is equivalent to 2685 PCR reactions. The result showed that the DNA isolated by urea method provides high quality pure DNA and high yield which is suitable for genotyping.

The purity of DNA extracted by this method was measured by ND-1000 spectrophotometer and running DNA on 0.8 $\%$ agarose gel. The purity of DNA was estimated by the ratio of absorbances at 260 nm (A260) and $280 \mathrm{~nm}$ (A280), A260/A280. The purity of DNA is considered to be best if it ranges between 1.8-2.0. In this study the average range was observed between 1.8-2.0 in both crops (Table 3 and 4). It indicates that there is no much contamination in all methods. Pure DNA was obtained from these protocols could be as a result of the RNase A treatment. It was reported that the absence of RNA are evidence of a good quality genomic DNA (Sambrook, 2001). The A260/A230 values for pure nucleic acid are often higher than the respective A260/A280 values. 
Fig.1 Agarose gel profile of Genomic DNA of all five methods with four replications in rice crop

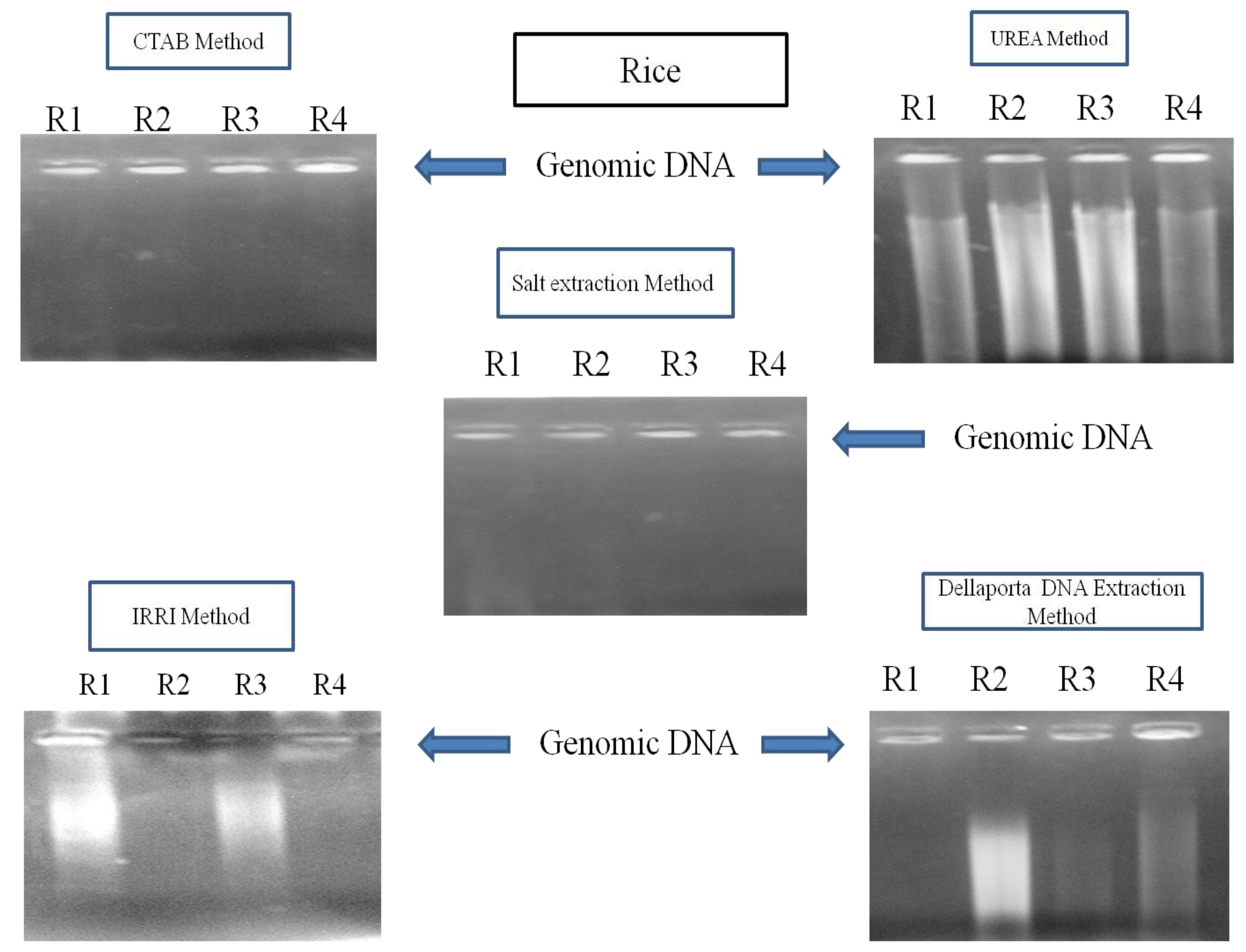


Fig.2 Agarose gel profile of Genomic DNA of all five methods with four replications in tomato crop

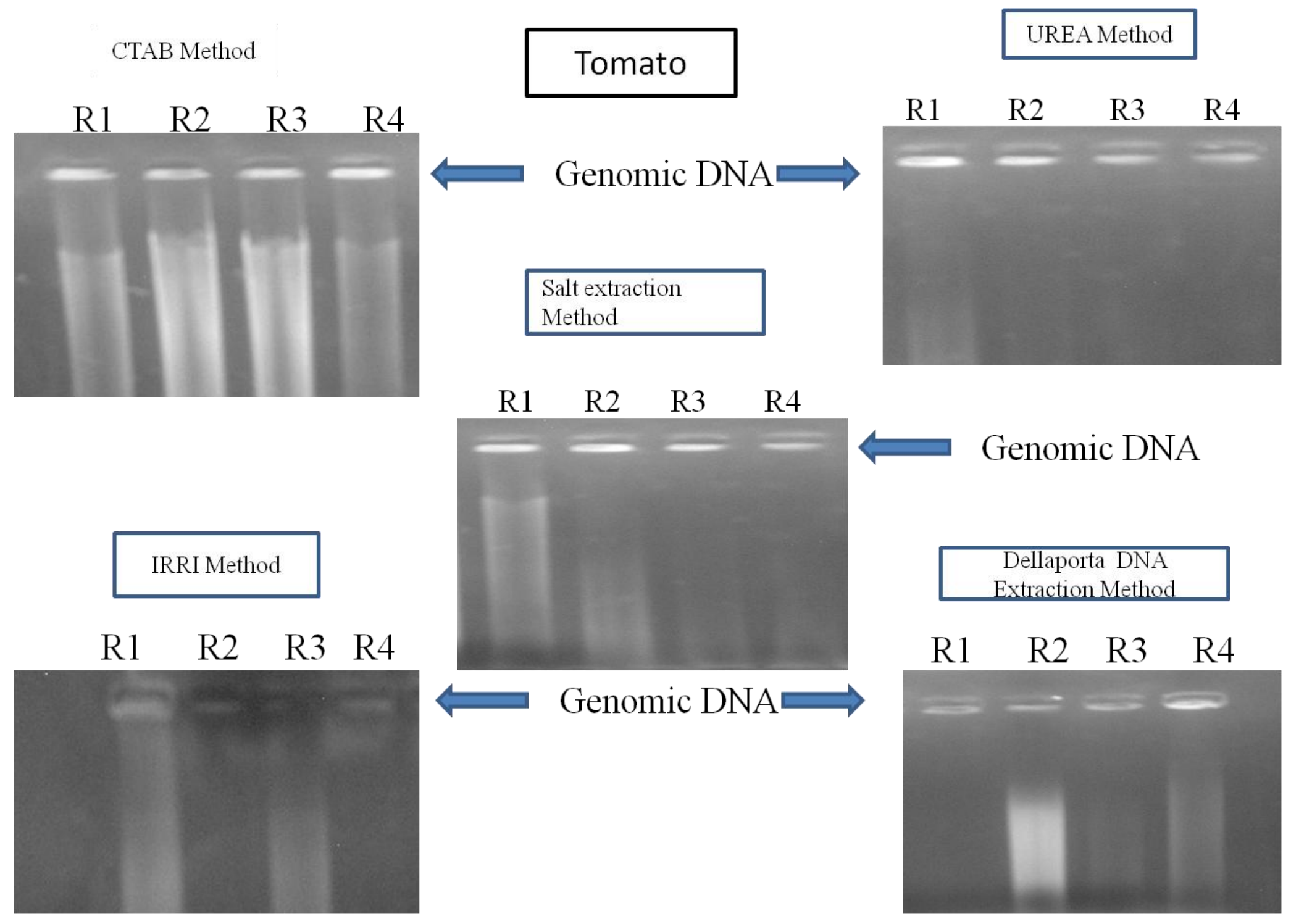


Table.1 Analysis of variance for amount of genomic DNA of rice and tomato

\begin{tabular}{|l|l|c|c|c|}
\hline \multicolumn{2}{|c|}{ Source of variation } & \multicolumn{2}{c|}{ Degrees of freedom } & \multicolumn{2}{c|}{ Mean sum of squares } \\
\hline Sl. No. & \multicolumn{3}{c|}{ Rice } & Tomato \\
\hline 1 & Treatments & 4 & $2749805.20^{*}$ & $3279977.20^{*}$ \\
\hline 2 & Error & 15 & $9413.13^{*}$ & $6628.40^{*}$ \\
\hline 3 & Total & 19 & & 169.65 \\
\hline 4 & CD $(0.01)$ & & 202.17 & 5.55 \\
\hline 5 & Coefficient of Variation & & 7.011 & \\
\hline
\end{tabular}

*significance at level $1 \%$

Table.2 Amount of genomic DNA of rice and tomato in replicated data

\begin{tabular}{|c|c|c|c|c|c|c|c|c|c|c|}
\hline Methods & \multicolumn{2}{|c|}{$\mathbf{R 1}(\mathbf{n g} / \boldsymbol{\mu l})$} & \multicolumn{2}{c|}{$\mathbf{R 2}(\mathbf{n g} / \boldsymbol{\mu l})$} & \multicolumn{2}{c|}{$\mathbf{R 3}(\mathbf{n g} / \boldsymbol{\mu l})$} & \multicolumn{2}{c|}{$\mathbf{R 4}(\mathbf{n g} / \mathbf{\mu l})$} & \multicolumn{2}{c|}{ Average $(\mathbf{n g} / \mathbf{\mu l})$} \\
\hline & Rice & Tomato & Rice & Tomato & Rice & Tomato & Rice & Tomato & Rice & Tomato \\
\hline $\begin{array}{c}\text { Doyle \& Doyle } \\
\text { CTAB Procedure }\end{array}$ & 2410 & 1521 & 2600 & 1390 & 2690 & 1460 & 2224 & 1305 & $2481 \mathrm{a}$ & $1419 \mathrm{abc}$ \\
\hline Urea Method & 1960 & 2710 & 1983 & 2640 & 1900 & 2790 & 1869 & 2600 & $1928 \mathrm{ab}$ & $2685 \mathrm{a}$ \\
\hline $\begin{array}{c}\text { Salt extraction } \\
\text { method }\end{array}$ & 860 & 750 & 890 & 900 & 880 & 790 & 878 & 960 & $877 \mathrm{~cd}$ & $850 \mathrm{bc}$ \\
\hline IRRI Method & 395 & 450 & 398 & 360 & 405 & 415 & 396 & 351 & $398.5 \mathrm{~d}$ & $394 \mathrm{c}$ \\
\hline $\begin{array}{l}\text { Dellaporta DNA } \\
\text { Extraction }\end{array}$ & 1190 & 2015 & 1250 & 1960 & 1231 & 2060 & 1269 & 1881 & $1235 \mathrm{bc}$ & $1979 \mathrm{ab}$ \\
\hline
\end{tabular}

Values followed by the same letters are not significantly different

Table.3 Evaluation of tomato genomic DNA samples extracted using five protocols according to

DNA purity and yield (ng/ul)

\begin{tabular}{|c|c|c|c|c|c|}
\hline \multirow{2}{*}{$\begin{array}{l}\text { Sl. } \\
\text { No. }\end{array}$} & \multirow[t]{2}{*}{ Methods } & \multirow{2}{*}{$\begin{array}{l}\text { Avg. DNA conc. } \\
\text { (ng/ul) }\end{array}$} & \multicolumn{2}{|c|}{ Avg. Purity of DNA obtained(nm) } & \multirow{2}{*}{$\begin{array}{l}\text { RNase A } \\
\text { Treatment }\end{array}$} \\
\hline & & & $260 / 280$ & $260 / 230$ & \\
\hline 1. & $\begin{array}{l}\text { Doyle \& Doyle } \\
\text { CTAB Procedure }\end{array}$ & 1419.37 & 1.89 & 1.99 & Yes \\
\hline 2. & Urea Method & 2685.22 & 1.83 & 2.00 & Yes \\
\hline 3. & $\begin{array}{l}\text { Salt extraction } \\
\text { method }\end{array}$ & 850.92 & 1.69 & 1.99 & Yes \\
\hline 4. & IRRI Method & 394.2 & 1.76 & 1.05 & Yes \\
\hline 5. & $\begin{array}{l}\text { Dellaporta DNA } \\
\text { Extraction }\end{array}$ & 1979.57 & 1.86 & 1.98 & Yes \\
\hline
\end{tabular}

Table.4 Evaluation of rice genomic DNA samples extracted using five protocols according to DNA purity and yield (ng/ul)

\begin{tabular}{|c|c|c|c|c|c|}
\hline \multirow{2}{*}{$\begin{array}{l}\text { Sl. } \\
\text { No. }\end{array}$} & \multirow[t]{2}{*}{ Methods } & \multirow{2}{*}{$\begin{array}{l}\text { Avg. DNA conc. } \\
\text { (ng/ul) }\end{array}$} & \multicolumn{2}{|c|}{ Avg. Purity of DNA obtained(nm) } & \multirow{2}{*}{$\begin{array}{l}\text { RNase A } \\
\text { Treatment }\end{array}$} \\
\hline & & & $260 / 280$ & $260 / 230$ & \\
\hline 1. & $\begin{array}{l}\text { Doyle \& Doyle } \\
\text { CTAB Procedure }\end{array}$ & 2481.36 & 1.85 & 2.2 & Yes \\
\hline 2. & Urea Method & 1928.06 & 2.00 & 2.01 & Yes \\
\hline 3. & $\begin{array}{l}\text { Salt extraction } \\
\text { method }\end{array}$ & 877.80 & 1.83 & 1.99 & Yes \\
\hline 4. & IRRI Method & 394.2 & 1.77 & 1.50 & Yes \\
\hline 5. & $\begin{array}{l}\text { Dellaporta DNA } \\
\text { Extraction }\end{array}$ & 1235.6 & 1.79 & 1.91 & Yes \\
\hline
\end{tabular}


Expected A260/A230 values are commonly in the range of 2.0-2.2. In present study the average range was observed between 2.0-2.2 except by IRRI method in both crops rice and tomato (Table 3 and 4).

The integrity of the extracted DNA was also analyzed by agarose gel electrophoresis. Both crop of genomic DNA were electrophoresed with four replications and visualized in gel documentation system. Intact DNA was observed in all samples. This clearly demonstrated that the isolated total DNA from isolates was of a high quality and could be used in downstream applications. The DNA band was visible in all samples except in IRRI method where the amount of DNA was low (394.2 $\mathrm{ng} / \mu \mathrm{l})$ in both crops rice and tomato (Figs. $1 \& 2$ ). The good quality of DNA extracted in our study is comparable to various other studies where it was reported that good quality DNA can be isolated without using liquid nitrogen (Chandra and Tewari, 2009; Sharma et al., 2010; Ferdous et al., 2012; Ambawat et al., 2017). The genomic DNA was isolated by five methods in both crops rice and tomato. The amount of DNA quantified and identified the urea method is best for tomato and Doyle \& Doyle CTAB Method is best rice crop. For high amount of DNA, the urea method can be used in tomato crops and Doyle \& Doyle CTAB Method can be used in rice crop for further genotyping of crops.

\section{Acknowledgement}

We thank Vaccine Lab, Department of Plant Biotechnology, University of Agricultural Sciences, GKVK, Bengaluru-560065, India and for providing lab facilities and Indian council of Agriculture Research for providing fellowship to pursue M.Sc. degree Also, the co-author is thankful to the University Grants Commission, Government of India for providing fellowship to pursue $\mathrm{Ph}$. D. degree.

\section{References}

Aljanabi, S.M., Martinez, I. 1997. Universal and rapid salt-extraction of high quality genomic DNA for PCR-based techniques. Nucleic Acids Res. 25: 4692-4693.

Chandra, A., and Tewari, S. 2007. Isolation of genomic DNA from Stylo species without liquid nitrogen suitable for RAPD and STS analysis. Cytologia. 72:287.

Chang, S., Puryear, J. and Cairney, J. 1993. A simple and efficient method for isolating RNA from pine trees. Plant Mol. Biol. Rep. 11:113-116.

Dellaporta, S. L., Wood, J. and Hicks, J. B. 1983. A plant DNA minipreparation: version I I. Pl. Molec. Biol. Reporter. 1: 19-21.

Dellaporta, S.L., Wood, J. and Hicks, J. B., 1983. A plant DNA minipreparation: versionI I. Pl. Molec. Biol. Reporter 1: 19-21.

Doyle, J.J. and Doyle, J.L. 1987. A rapid DNA isolation procedure for small quantities of fresh leaf tissue. Phytochem Bull. 19: 1115.

Doyle, J.J. and Doyle, J.L. 1990. Isolation of plant DNA from fresh tissue. Focus 12: 13-15.

Ferdous, J., Hanafi, M.M., Rafii, M.Y. and Muhammad, K. 2012. A quick DNA extraction protocol: without liquid nitrogen in ambient temperature. Afr. J. Biotech. 11:6956-6964.

Guo-Liang, W., Rod, A.W. and Paterson, A.H. 1993. PCR amplification from single seeds, facilitating DNA marker-assisted breeding. Nucl. Acid Res. 21: 2517- 2527.

Gupta, P.K., Varshney, R.K., Sharma, P.C. and Ramesh, B. 1999. Molecular markers and their applications in wheat breeding. Plant Breeding. 118: 369-390.

Healey, A., Furtado, A., Cooper, T. and Henry, R.J. 2014. Protocol: a simple method for extracting next-generation sequencing quality genomic DNA from recalcitrant plant species. Plant Methods. 10:21.

Huang, J., Ge, X. and Sun, M. 2000. Modified CTAB protocol using a silica matrix for isolation of plant genomic DNA. Biotechniques. 28: 432- 434.

Jobes, D.V., Hurley, D.L., and Thien, L.B. 1995. Plant DNA isolation: A method to efficiently remove polyphenolics, 
polysaccharides and RNA. Taxon. 44: 349386.

Kang, T.J., Yang, M.S. 2004. Rapid and reliable extraction of genomic DNA from various wild-type and transgenic plants. $B M C$ Biotech. 4:20.

Laxmi-prasanna, B., Rao, P.J.M., Srividhya, A., Yamini, K.N., and Murthy, K.G.K. 2013. Standardization of DNA extraction protocol in greengram (Vigna radiata (L.) Wilczek). Int. J. Appl. Pharma Tech. 4(4): 86-91.

Loomis, W.D. 1974. Overcoming problems of phenolics and quinines in the isolation of plant enzymes and organelles. Methods Enzymol. 31: 528-545.

McCarthy, P.L., and Berger, P.H. 2002. Rapid identification of transformed wheat using a half-seed PCR assay prior to germination. Biotechniques. 32: 560-564.

Nalini, E., Jawali, N. and Bhagwat, S.G., 2003. A simple method for isolation of DNA from plants suitable for long Term storage and DNA marker Analysis. National Symposium on "The Role of Biotechnology in the Development of the Indian Economy" at Vaze College, Mumbai.

Rawat, S., Joshi, G., Annapurna, D., Arunkumar, A.N. and Karaba, N.N. 2016. Standardization of DNA Extraction Method from Mature Dried Leaves and ISSR-PCR Conditions for Melia dubia Cav. -A Fast growing multipurpose tree species. American J. Plant Sci. 7: 437-445.

Rogers, S.O., and Bendich, A.J. 1985. Extraction of DNA from milligram amounts of fresh, herbarium, and mummified plant tissue. $\mathrm{Pl}$.
Molec. Biol. 5: 69-76.

Sajib, A.A., Bhuiya, M.A.I. and Huque, R. 2017. A Simple, efficient and rapid method for good quality DNA extraction from rice grains. Rice Sci. 24(2): 119-122.

Sambrook and Russell. 2001. Molecular Cloning: A Laboratory Manual (3rd ed.). Cold Spring Harbor Laboratory Press.

Sharma, P., Joshi, N. and Sharma, A. 2010. Isolation of genomic DNA from medicinal plants without liquid nitrogen. Indian $J$. Exp. Bio. 48: 610- 614.

Sharma, R., John, S.J., Damgaard, D.M. and McAllister, T.A. 2003. Extraction of PCRquality plant and microbial DNA from total rumen contents. BioTechniques. 34: 92-97.

Sperisen, C., Gugerli, F., Büchler, U., Mátyás, G. 2000. Comparison of two rapid DNA extraction protocols for gymnosperms for application in population genetic and phylogenetic studies. Genet. 7: 133-136.

Supriya, A., Kumar, R., Singh, S. and Yadav, R., 2017. An Easy, Quick and Cost Effective Method of High Quality DNA Extraction from Mungbean [Vigna radiata (L.) Wilczek] Without Liquid Nitrogen. Int.J.Curr.Microbiol.App.Sci. 6(9): 26952703.

Zheng, K., Subudhi, P.K., Domingo, J., Maopantay, G. and Huang, N. 1995. Rapid DNA isolation for marker assisted selection in rice breeding. Rice Genet. Newslett. 12, 48.

\section{How to cite this article:}

Shiv Mani Dubey, Sujeet Kumar, S.H. Antre and Ramanjini Gowda, P.H. 2017. Comparative Study of High Quality Genomic DNA Extraction Protocols in Rice and Tomato Crops. Int.J.Curr.Microbiol.App.Sci. 6(11): 2763-2772. doi: https://doi.org/10.20546/ijcmas.2017.611.327 